\title{
Viral dynamics: a model of the effects of size, shape, motion and abundance of single-celled planktonic organisms and other particles
}

\author{
Alexander G. Murray, George A. Jackson \\ Department of Oceanography, Texas A \& M University, College Station, Texas 77843, USA
}

\begin{abstract}
The transport of aquatic viruses to particles can be described in terms of diffusive transport from solution. Such transport is influenced by motion of the water relative to the particle. Because transport rate is determined purely by physical factors it is independent of whether the particle is a host or non-host organism. The low viral diffusivity relative to that for dissolved nutrients makes transport enhancement from organism swimming more important for viruses. The virus contact rate with bacteria is relatively unaffected by such motions because of small bacterial sizes. Transport rates for phytoplankton and protozoa can increase over an order of magnitude when swimming motions are considered. Although larger organisms have much higher transport rates per individual, their far lower concentrations in sea water should make small organisms the preferred targets for viruses. Rates of host-virus interactions in culture are closely related to predictions from transport theory. There is a fairly close relationship between bacterial populations and virus disappearance rates in the marine environment, suggesting that non-host organisms are a major cause of viral mortality at the higher ionic strengths typical of sea water. Other factors, such as UV radiation, must also be included when estimating viral mortality in seawater.
\end{abstract}

\section{INTRODUCTION}

Viruses have been suspected of controlling marine bacterial populations since the 1920 s. Viruses capable of infecting bacteria, known as bacteriophages or phages, have been isolated from seawater for at least 30 yr (Carlucci \& Pramer 1960). The basic transfer dynamics of viruses to bacteria in solution were described in the early 1930s (Schlesinger 1932). Information on rates of viral reproduction in laboratory bacteria was available by the 1940s (Delbruck 1945). Interest in bacteriophage dynamics, stimulated by the possible medical benefits, declined with the introduction of antibiotics; interest in marine bacteriophages was limited because bacteria and microplankton were believed to be insignificant in marine ecosystems. The inference drawn was that phage production could be important only in polluted water (Carlucci \& Pramer 1960).

Wiggins \& Alexander (1985) described bacterial population levels needed to support net viral produc- tion, but concluded that a threshold bacterial population of $10^{4} \mathrm{~cm}^{-3}$ is rarely reached in the sea. Data then becoming available showed that this population size is, however, commonly exceeded. With the advent of epifluorescent microscopy (Zimmerman \& Meyer-Reil 1974), it became apparent that there were large numbers of bacteria, picophytoplankton and heterotrophic nanoflagellates in seawater. The population levels of these organisms were high enough that they were potentially vulnerable to viruses. It was not until the eve of the 1990s that viruses were shown to be abundant, attacking both bacteria and phytoplankton (Berg et al. 1989, Proctor \& Fuhrman 1990, Suttle et al. 1990).

Some viruses, known as temperate viruses, may be passed from generation to generation of host encoded in the host's genes. If such a virus is to spread it must eventually become virulent, infecting a new line of hosts. The virus must pass through the water if it is to spread in the absence of vectors and sexual transfer. It cannot reproduce while in the water but it can be destroyed. The time away from its host poses a risk to 
the virus, with the longer the delay in finding a new host, the greater the risk of its destruction. Processes transporting viruses to hosts are critical to viral survival.

There has been considerable advance in the development of the mathematics of mass transfer to small aquatic organisms between the early work on virus dynamics and the recent measurements of high viral populations and productivity. Advances include work on nutrient uptake by algal cells (Munk \& Riley 1952), chemoreception by bacteria (Berg \& Purcell 1977) and heat and mass transfer to particles in various flow fields (e.g. Frankel \& Acrivos 1968, Batchelor 1979). There can be a strong relationship between solute transfer and water motion. An important difference between virus and small molecule transfer is that the diffusion coefficients for viruses are only $1 \%$ of those for simple solutes. As a result, organism motion relative to the fluid can have a greater impact on transport of viruses than of small nutrient molecules.

Viral dynamics comprises a major component of the marine ecosystem that is, despite a promising start and plentiful modern tools, without an adequate theoretical description. The following is an attempt to describe the interactions of particle shape, size and speed on viral contact. In this paper, we discuss viral transport to particles in some detail, deriving the maximum contact rate. In order to use this we discuss viral adsorption following contact with a target particle. We compare this approach with information on the uptake rate of viruses in culture (particularly pure cultures) and the removal rate of exotic viruses (such as human enteric viruses) in sea water. We consider the vulnerability of various host populations to infection using ideal and real biomass distributions.

\section{PARTICLE-VIRUS CONTACT DYNAMICS}

As the following model describes the random encounters of viruses and particles, the only properties of a spherical particle that are important are its diameter and speed. Therefore, the same equations describe maximum contact rates with host and non-host organisms as well as with non-living particles. What happens after contact depends on the nature of the particle

\section{Underlying concepts}

A small particle, such as a virus, is subject to the random wandering of Brownian motion. Thus, viruses obey the laws of diffusion in their approach to larger particles such as hosts, non-host organisms or nonliving particles. Diffusion transport depends on diffu- sivity of the solute and the diffusion gradient. The former is fixed for a given virus (if we consider it a solute). The latter varies with motions in the fluid. Sometimes these motions are in turn a result of organism behaviour. It is our intention to use the laws describing diffusion and fluid motion as the basis for the calculation of transport rates of viruses to particles.

A viral diffusion coefficient $D_{v}$ is typically $5 \times$ $10^{-8} \mathrm{~cm}^{2} \mathrm{~s}^{-1}$ (Schlesinger 1932, Dubin et al. 1970), about 2 orders of magnitude less than the diffusivities of nutrients (Berg 1983). As a result, fluid flow generated by particle motion or shear enhances viral transport to a particle more than it enhances transport of a small molecule. This enhancement is expressed as the ratio of transport for a given fluid flow to that for purely diffusive transport and is known as the Sherwood number $S h$. The Sherwood number for pure diffusion $S h_{0}$ is 1 . The Sherwood number is the factor by which diffusion transport is increased due to local fluid motion. In order to calculate the actual transport rate, one must calculate the diffusive transport as well as the Sherwood number and then multiply the two. (Note that some authors use 2 or $4 \pi$ for the $S h_{0}$ of a sphere, e.g. Batchelor 1979).

$S h$ can be related to the Peclet number, $P e=U L / D_{\mathrm{v}}$, where $U$ is a characteristic velocity that depends on the flow regime and $L$ is a characteristic length of the particle. The characteristic length for a sphere used here is its diameter. $P$ e is the diffusion equivalent of the Reynolds number Re. With kinematic viscosity $\nu=\mu / \rho$ about $10^{-2} \mathrm{~cm}^{2} \mathrm{~s}^{-1}$ (Hughs \& Brighton 1991), Peclet numbers for viral transport are more than 5 orders of magnitude larger than $R e$.

Flow fields around particles have been most intensively studied for 2 cases. In one, the fluid is fixed and the particle moves through it. This is equivalent to the fluid being still and the particle moving through it by either swimming or sinking. The other in which the particle is fixed and the fluid moves in opposite directions on either side of it (linear shear). Sh has a different relationship to $P e$ which depends on different parameters in these 2 cases. Thus 2 sets of equations need to be considered.

\section{Mass transfer basics}

Transport rate modeling starts with simple diffusion to a single sphere in the absence of fluid motion (Schlesinger 1932):

$$
J_{s}=2 \pi d D_{v} V
$$

where $J_{s}$ is the transport rate of viruses to a sphere of diameter $d_{i}$ and $V$ the concentration of viruses. (Symbols used in this paper are summarized in 
Table 1. Definition of symbols

\begin{tabular}{|c|c|c|}
\hline Symbol & Description & Unit \\
\hline$B$ & Bacteria concentration & no. $\mathrm{cm}^{-3}$ \\
\hline$c$ & Volume clearance rate per particle & $\mathrm{cm}^{3} \mathrm{~s}^{-1}$ \\
\hline$c_{0}$ & c for simple diffusion & $\mathrm{cm}^{3} \mathrm{~s}^{-1}$ \\
\hline$c_{\mathrm{d}}$ & cestimated from $k_{\mathrm{d}}$ & $\mathrm{cm}^{3} \mathrm{~s}^{-1}$ \\
\hline$d$ & Diameter of cylinder or sphere & $\mathrm{cm}$ \\
\hline$d s$ & $\begin{array}{l}\text { Spherical equivalent diameter } \\
\text { of cylinder }\end{array}$ & $\mathrm{cm}$ \\
\hline$d_{v}$ & Viral diameter & $\mathrm{cm}$ \\
\hline$D_{\mathrm{v}}$ & Diffusivity of virus & $\mathrm{cm}^{2} \mathrm{~s}^{-1}$ \\
\hline$J$ & $\begin{array}{l}\text { Diffusion transport of viruses } \\
\text { to particle }\end{array}$ & no. $s^{-1}$ \\
\hline$J_{c}$ & $J$ for a cylinder & no. $s^{-1}$ \\
\hline$J_{s}$ & $J$ for a sphere & no. $s^{-1}$ \\
\hline$k$ & Specific rate of viral removal & $s^{-1}$ \\
\hline$k_{\mathrm{d}}$ & Viral decay rate & $s^{-1}$ \\
\hline$L$ & $\begin{array}{l}\text { Length of cylinder, } \\
\text { characteristic length }\end{array}$ & $\mathrm{cm}$ \\
\hline$P$ & Particle concentration & no. $\mathrm{cm}^{-3}$ \\
\hline $\mathrm{Pe}$ & Peclet number & - \\
\hline$R$ & Total viral attachment rate & no. $\mathrm{cm}^{-3} \mathrm{~s}^{-1}$ \\
\hline$S h$ & Sherwood number & - \\
\hline$S h_{0}$ & Sherwood number for $P e=0, S h_{0}=1$ & - \\
\hline$S h_{\operatorname{sh}}$ & Sherwood number for shear & - \\
\hline$S h_{\mathrm{v}}$ & $\begin{array}{l}\text { Sherwood number for } \\
\text { particle swimming/settling }\end{array}$ & - \\
\hline$t$ & Time & $\mathrm{s}$ \\
\hline$T$ & Absolute temperature & K \\
\hline$U$ & Characteristic velocity of particle & $\mathrm{cm} \mathrm{s}^{-1}$ \\
\hline$V$ & Virus concentration & no. $\mathrm{cm}^{-3}$ \\
\hline$v$ & Swimming velocity & $\mathrm{cm} \mathrm{s}^{-1}$ \\
\hline$w$ & Fall rate & $\mathrm{cm} \mathrm{s}^{-1}$ \\
\hline$\gamma$ & Shear & $5^{-1}$, \\
\hline$\mu$ & Viscosity & $\mathrm{g} \mathrm{cm}^{-1} \mathrm{~s}^{-1}$ \\
\hline$v$ & Kinematic viscosity & $\mathrm{cm}^{2} \mathrm{~s}^{-1}$ \\
\hline
\end{tabular}

Table 1). Like all of the mass transport calculations made here, Eq. 1 assumes that all viruses disappear upon contacting the particle.

A cylinder can approximate many non-spherical shapes. By changing the length $L$ to diameter $d$ ratio, the shape can be changed from a disc to a needle. The transport rate to a cylinder $J_{c}$ is given by:

$$
J_{c}=2 \pi d_{s} D_{v} V\left[0.52\left(\frac{L}{d}\right)^{-0.33}+0.45\left(\frac{L}{d}\right)^{0.33}\right]
$$

(Clift et al. 1978) where $d$ is the cylinder's diameter; and $d_{s}$ is the volume-equivalent spherical diameter. The effect of shape $(L / d)$ relative to that of a sphere of the same volume is given by the factor within the square brackets. Using Eq. 2 we can show that particle shape has relatively little effect on viral transport rate. The maximum diffusion rate is 1.4 times the minimum for $0.125<L / d<8$, and the factor is less than 1.1 over most of the range. Because representing plankton as spheres does not greatly affect viral transport rate, all subsequent analysis is for viral transport to spherical particles.
Asymptotic solutions exist for the Sherwood number in the case of a spherical particle moving relative to the fluid that are approximately correct where $P$ e tends to zero or infinity (Clift et al. 1978):

$$
\begin{gathered}
S h_{\mathrm{v}}=1+\frac{1}{4} P e \quad P e \rightarrow 0 \\
S h_{\mathrm{v}}=0.5\left(0.92+0.991 P e^{1 / 3}\right) \quad P e \rightarrow \infty
\end{gathered}
$$

The asymptotic solutions are only valid for small or large values of $P e$. The intermediate range of $P e$ is important for viral transport. An approximate solution, accurate to $2 \%$, is (Clift et al. 1978):

$$
S h_{\mathrm{v}}=0.5\left[1+(1+P e)^{1 / 3}\right] \quad 0.1<P e<10^{4}
$$

The situation for sheared fluid flow is complicated by the variety of possible motions (Batchelor 1979). Approximate solutions exist for $S h$ in simple linear shear (Acrivos 1971). As Pe becomes larger, Sh tends to a constant due to the trapping of water around the spinning particle (Acrivos 1971).

$$
\begin{array}{lrl}
S h_{\mathrm{sh}}=1+0.36 P e^{1 / 2} & P e \ll 1, & R e \ll 1 \\
S h_{\mathrm{sh}}=1.009 P e^{1 / 3} & 10<P e<88 & R e \ll 1 \\
S h_{\mathrm{sh}}=4.5 P e^{0}=4.5 & P e \rightarrow \infty & R e \ll 1
\end{array}
$$

Eq. 7 is actually for pure shear (Batchelor 1979) but does work well to interpolate between the domains of Eqs. 6 and 8. The maximum value for $S h$ is 4.5 .

\section{Contact rate parameters for viruses}

Diffusivity for a spherical virus can be calculated as (Berg 1983):

$$
\begin{aligned}
D_{v} & =\frac{k T}{3 \pi \mu d_{v}} \\
& \sim \frac{3.16 \times 10^{-13} \mathrm{~cm}^{3} \mathrm{~s}^{-1}}{d_{v}} \text { at } 283 \mathrm{~K}
\end{aligned}
$$

where $k$ is the Boltzmann constant; $T$ temperature $(K)$; $\mu$ viscosity; and $d_{v}$ viral particle diameter. Because viral diameter varies from 10 to $200 \mathrm{~nm}$ (Dubin et al. 1970, Heldal \& Bratbak 1991, Van Etten et al. 1991), diffusivity ranges from $1.6 \times 10^{-8}$ to $3 \times 10^{-7} \mathrm{~cm}^{2} \mathrm{~s}^{-1}$ (Table 3 ). The diffusion coefficient for non-spherical viruses may differ from that calculated for a sphere.

A settling diatom or a swimming dinoflagellate moves relative to the water at a speed $U$ which is used to calculate Pe. Jackson (1990) used the data in Smayda (1970) to derive a relationship between algal settling speed $w\left(\mathrm{~cm} \mathrm{~s}^{-1}\right)$ and diameter $(\mathrm{cm})$ :

$$
w=1.1 d^{1.17}
$$

The velocity associated with active swimming motion 
$v$ is more variable. As larger organisms tend to move more slowly relative to their lengths, the relationship used is not a linear relationship to body length but rather to a fractional power of body length. A collection of swimming speeds for bacterla (Vaituzis \& Doetsch 1969), phytoplankton (Bauerfeind et al. 1986) and flagellate and ciliate protozoa (Roberts 1981) show a weak relationship with size (Fig. 1). We have used a relationship which represents the upper bound of swimming speeds because the faster swimming organisms have maximal contact rates and greatest $S h$ :

$$
v=2.5 d^{0.7}
$$

where $d$ is in $\mathrm{cm}$ and $v$ is in $\mathrm{cm} \mathrm{s}^{-1}$. Organisms attached to marine snow may be exposed to increased fluid flow and therefore have enhanced viral contact rates. Logan \& Dettmer (1990) suggested that fluid velocity within marine snow is nearly equivalent to free field velocity. As marine snow sinks at up to $1 \mathrm{~mm} \mathrm{~s}$, bacteria could have $P e$ boosted by 2 orders of magnitude over free swimming bacteria.

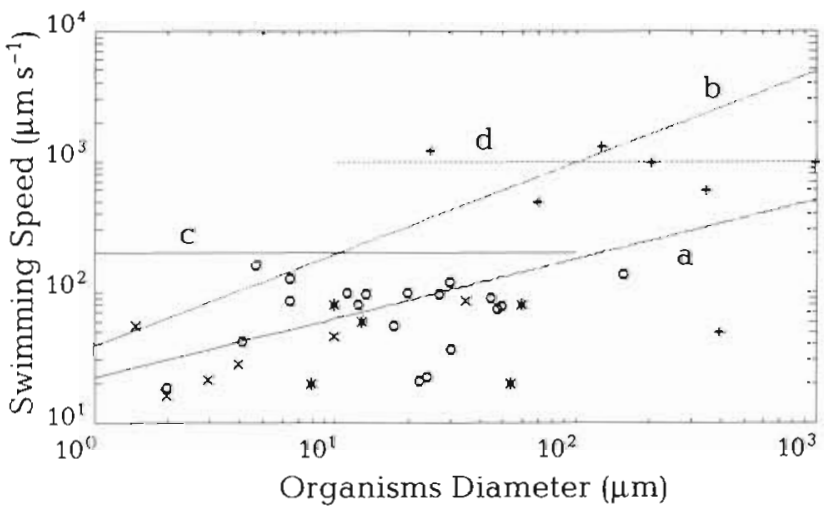

Fig. 1. Swimming speeds of organisms of various sizes. Eq. 11 provides an upper limit for swimming speeds. As a result, it is greater than the regression lıne for all points. We have used it in order to emphasize the potential importance of swimming speed. In addition, the data of Fenchel (1987) support a higher swimming speed for flagellates than do the older data of Roberts (1981). Data: (o) phytoplankton (Bauerfeind et al. 1986); (*) flagellates (Roberts 1981); (+) ciliates (Roberts 1981); (x) bacteria (Vaituzis \& Doetsch 1969). Calculations: (a) line for linear regression analysis of log-transformed data, $v_{s}=0.15 d^{0.471}\left(r^{2}=0.36\right)$; (b) Eq 11 ; (c) flagellate swimming speed, $v_{s}=200 \mu \mathrm{m} \mathrm{s}^{-1}$ (Fenchel 1987); (d) ciliate swimming speed, $v_{s}=1000 \mu \mathrm{m} \mathrm{s}^{-1}$ (Fenchel 1987)

Transport to larger particles is more influenced by particle motion than that to smaller particles (Fig. 2). A $1 \mu \mathrm{m}$ particle, such as a bacterium, shows little increase in transport rate, even when swimming at $50 \mu \mathrm{m} \mathrm{s}^{-1}$ A particle with a diameter of $125 \mu \mathrm{m}$ increases the viral transport rate 10 -fold by changing from 0 to $1250 \mu \mathrm{m} \mathrm{s}^{-1}$. Even when it swims at a speed of 1 body-length $\mathrm{s}^{-1}$ its contact rate changes several

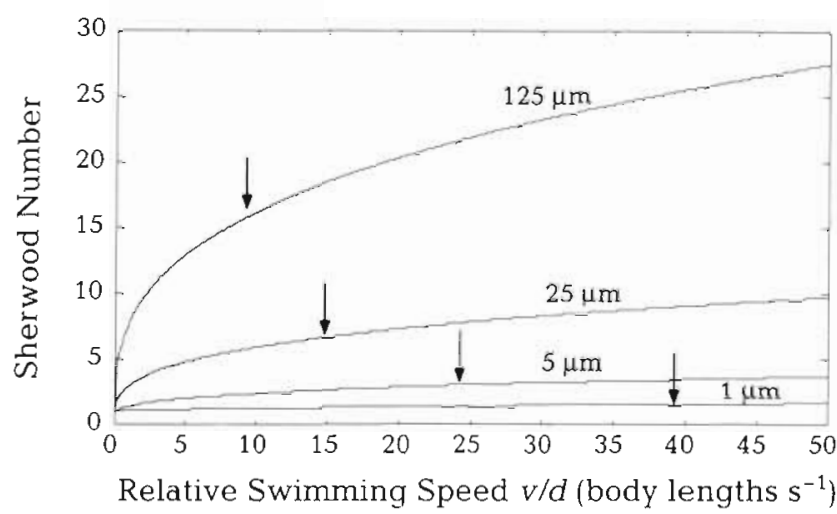

Fig. 2. Effect of speed relative to host's body length on contact rate with viruses for different particle sizes. Numbers shown are for particle diameter, arrows indicate swimming speed calculated by Eq. 11. Not only are larger hosts more sensitive to movement, they are very sensitive to small movements. Sh calculated from Eq. 5

fold. The swimming speed of a $125 \mu \mathrm{m}$ organism is 9 body-length $\mathrm{s}^{-1}$ (Eq. 11). This speed is in a range where small changes in $v$ affect $S h$ fairly strongly. Thus, viral transport rate for $125 \mu \mathrm{m}$ organisms may vary if swimming speed is not constant. For the smaller $25 \mu \mathrm{m}$ organisms swimming speeds are in ranges that are fairly insensitive to changes in $S h_{\text {; }}$ for the smallest $1 \mu \mathrm{m}$ organisms, there is almost no effect of motion.

Shear is usually unimportant to transport relative to the effect of swimming. For example at a high oceanic value of $\gamma=0.1 \mathrm{~s}^{-1}$ (e.g. Gregg et al. 1985), shear has less effect on viral contact rate than movement of 1 body-length $\mathrm{s}^{-1}$, which is a minimal swimming speed (Fig. 3). Shear can be neglected for motile organisms but can still be important for small or low density nonmotile organisms which sink only slowly (Table 2 ). We have used the larger of $S h_{\mathrm{sh}}$ and $S h_{v}$ when calculating $J$.

The total rate at which viruses attach to particles $R$ is then

$$
\begin{aligned}
R & =J \operatorname{Sh} P \\
& =\left(\operatorname{Sh} 2 \pi d D_{v}\right) V P
\end{aligned}
$$

where $P$ is the target particle concentration. The specific rate of virus removal $k$ is then

$$
\begin{aligned}
k & =R / V \\
& =2 \pi d D, S h P
\end{aligned}
$$

An equivalent volume clearance rate for a particle is given by

$$
\begin{aligned}
c & =J S h / V \\
& =2 \pi d D_{v} S h
\end{aligned}
$$

Particle movement and shear affect mass transport to the different representative organisms differently (Table 2). Because larger particles consistently have 


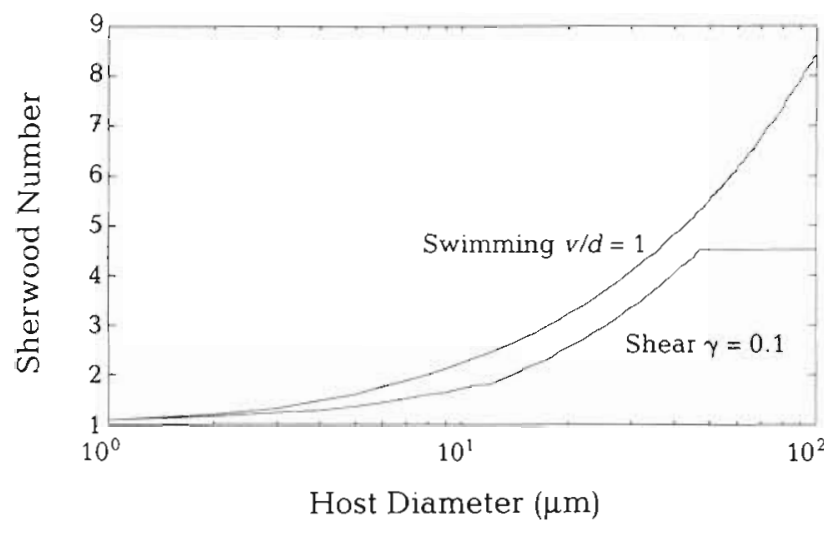

Fig. 3. Sherwood number for spheres moving at 1 body length $\mathrm{s}^{-1}$, or stationary and subject to shear of $0.1 \mathrm{~s}^{-1}$ (equation for shear changes from Eq. 6 to Eq. 7 at $P e=5$ ). Calculated using Eqs. $5 \& 6-8$

larger $S h$, a simple diffusion description of viral transport is less accurate for them. Despite relatively rapid swimming speeds, transport by pure diffusion is an adequate description for bacteria. Swimming increases transport by only about 0.5 . To the extent that Logan \& Dettmer (1990) are correct about water velocity inside falling marine snow particles, bacteria attached to them have a significantly enhanced contact rate. Because less than 0.1 of marine bacteria are attached to particles (Azam \& Hodson 1977), there should be a small impact on the total number of bacterium-virus contacts. The matrix of the marine snow could itself adsorb viruses and thus slow down contact. If there is significant mortality of trapped viruses the enhancement of bacterial contacts could be reduced, or reversed. The effects of fluid shear and organism sinking are relatively small for bacteria. Like bacteria, flagellates attached to marine snow could have significantly enhanced contact rates over those for free individuals. For still larger organisms, such as the hypothetical dinoflagellates (Table 2), values of Sh are still larger. The shear effect is still relatively small compared to those for swimming and settling. Sinking marine snow particles could no longer offer an advantage. Thus, the inadequacies of a simple diffusion description of viral transport increase with increased organism size.

\section{EFFECT OF CONTACT BETWEEN VIRUS AND PARTICLE}

When a virus comes into contact with a particle it may adsorb to the surface, be destroyed, or return to solution. The first 2 cases determine whether the host is infected or survives, the last case reduces the effective contact rate. Adsorption to the particle is an

Table 2. Transport properties of organisms of different sizes. $C_{0}$ is $c$ for $S h_{0} . D_{v}=5 \times 10^{-8} \mathrm{~cm}^{2} \mathrm{~s}^{-1}$ Particle concentrations calculated assuming that each type of particle occupies $10^{-6}$ of the total volume

\begin{tabular}{|c|c|c|c|c|}
\hline Type: & Bacterium & Flagellate & Small dinoflagellate & Large dinoflagellate \\
\hline Diameter ( $\mu \mathrm{m})$ & 1 & 5 & 25 & 125 \\
\hline$c_{0}\left(\mu m^{3} s^{-1}\right)$ & 31.4 & 157 & 790 & 3930 \\
\hline Volume $\left(\mu \mathrm{m}^{3}\right)$ & 0.52 & 65 & 8181 & $1.02 \times 10^{6}$ \\
\hline$P\left(\right.$ cells $\left.\mathrm{cm}^{-3}\right)$ & $1.9 \times 10^{6}$ & $1.53 \times 10^{4}$ & 122 & 0.98 \\
\hline \multicolumn{5}{|l|}{ Speed $\left(\mu \mathrm{m} \mathrm{s}^{-1}\right)$} \\
\hline$v$, swimming & 39 & 121 & 373 & 1149 \\
\hline$w$, sinking & 0.24 & 1.52 & 10.0 & 63.4 \\
\hline On marine snow & 1000 & 1000 & 1000 & 1000 \\
\hline \multicolumn{5}{|l|}{ Sherwood numbers (Sh) } \\
\hline Swimming & 1.53 & 2.98 & 6.66 & 15.8 \\
\hline Sinking & 1.01 & 1.18 & 2.35 & 6.33 \\
\hline On marine snow & 3.43 & 5.50 & 9.05 & 15.12 \\
\hline Shear $\gamma=0.1 \mathrm{~s}^{-1}$ & 1.05 & 1.25 & 2.34 & 4.5 \\
\hline Shear $\gamma=0.1 \mathrm{~s}^{-1}$ & 1.02 & 1.08 & $1.4^{\mathrm{a}}$ & 3.18 \\
\hline Shear $\gamma=0.1 \mathrm{~s}^{-1}$ & 1.00 & 1.02 & 1.13 & $1.7^{\mathrm{a}}$ \\
\hline \multicolumn{5}{|l|}{$c\left(\mu \mathrm{m}^{3} \mathrm{~s}^{-1}\right)$} \\
\hline Swimming & 48 & 468 & 5230 & 62050 \\
\hline Sinking & 32 & 185 & 1850 & 24860 \\
\hline Shear $\gamma=0.1 \mathrm{~s}^{-1}$ & 33 & 196 & 1840 & 17640 \\
\hline \multicolumn{5}{|l|}{$k\left(s^{-1}\right)$} \\
\hline Pure diffusion & $6.0 \times 10^{-5}$ & $2.3 \times 10^{-6}$ & $9.6 \times 10^{-8}$ & $3.8 \times 10^{-9}$ \\
\hline Swimming & $9.1 \times 10^{-5}$ & $7.2 \times 10^{-6}$ & $6.3 \times 10^{-7}$ & $6.2 \times 10^{-8}$ \\
\hline Sinking & $6.1 \times 10^{-5}$ & $2.8 \times 10^{-5}$ & $2.3 \times 10^{-7}$ & $2.4 \times 10^{-8}$ \\
\hline Shear $\gamma=0.1 \mathrm{~s}^{-1}$ & $6.3 \times 10^{-5}$ & $3.0 \times 10^{-6}$ & $2.2 \times 10^{-7}$ & $1.8 \times 10^{-8}$ \\
\hline
\end{tabular}


Table 4. Comparison of observed $\left(c_{d}\right)$ and calculated $(c)$ viral removal rates in culture experiments. All contact rates presented in Schwartz (1976) have been divided by 10 because the 'optimal' uptake rate (Eq. 3 of that paper) was erroneously evaluated as 500 rather than $50 \mathrm{~mm}^{3} \mathrm{~s}^{-1}$. Environments: a: $\left[\mathrm{Mg}^{2+}\right]=2 \mathrm{mM}$ b: $\left[\mathrm{Mg}^{2+}\right]=20 \mathrm{mM} ; \mathrm{c}: 6000$ receptors cell ${ }^{-1}$; d: 30 receptors cell-1. $D_{\mathrm{v}}=5 \times 10^{-8} \mathrm{~cm}^{2} \mathrm{~s}^{-1}$

\begin{tabular}{|c|c|c|c|c|c|c|c|}
\hline Host & Virus & Condition & $\begin{array}{c}d \\
(\mu \mathrm{m})\end{array}$ & $\begin{array}{c}v \\
\left(\mu \mathrm{m} \mathrm{s}^{-1}\right)\end{array}$ & $\left(\mu \mathrm{m}^{3} \mathrm{~s}^{-1}\right)$ & $\begin{array}{c}c \\
\left(\mu m^{3} s^{-1}\right)\end{array}$ & Source \\
\hline \multirow{5}{*}{ Escherichia coli } & \multirow{5}{*}{ Coli 88} & Dead & - & - & 13 & - & Schlesinger (1932) \\
\hline & & Model & 0.9 & 0 & - & 27 & Schlesinger (1932) \\
\hline & & Live & - & - & 33 & - & Schlesinger (1932) \\
\hline & & Model & 0.9 & 16 & - & 35 & Schlesinger (1932) \\
\hline & & Model & 0.9 & 36 & - & 40 & Schlesinger (1932) \\
\hline \multirow[t]{7}{*}{ Escherichia coli } & \multirow[t]{7}{*}{$\lambda$} & $a, c$ & - & - & 23 & - & Schwartz (1976) \\
\hline & & $\mathrm{a}, \mathrm{d}$ & - & - & 3.4 & - & Schwartz (1976) \\
\hline & & $\mathrm{b}, \mathrm{c}$ & - & - & 11 & - & Schwartz (1976) \\
\hline & & $b, d$ & - & - & 0.17 & - & Schwartz (1976) \\
\hline & & Model & 1.6 & 0 & - & 50 & Schwartz (1976) \\
\hline & & Model & 1.6 & 16 & - & 71 & Schwartz (1976) \\
\hline & & Model & 1.6 & 49 & - & 91 & Schwartz (1976) \\
\hline \multirow[t]{3}{*}{ Micromonas pusilla } & \multirow[t]{3}{*}{ MPV } & Observed & - & - & 120 & - & Schwartz (1976) \\
\hline & & Model & 2 & 20 & - & 94 & Waters \& Chan (1982) \\
\hline & & Model & 2 & 63 & - & 120 & Waters \& Chan (1982) \\
\hline
\end{tabular}

Waters \& Chan (1982) observed that after $1 \mathrm{~h}$, the motile alga Micromonas pusilla present at a concentration of $7.1 \times 10^{6}$ cells $\mathrm{cm}^{-3}$ removed 0.95 of the viruses initially present. This is equivalent to $k_{\mathrm{d}}=$ $8.3 \times 10^{4} \mathrm{~s}^{-1}$. The transport calculations using Eq. 12 (if $S h=S h_{v}$ ) predict $k=9.2 \times 10^{4} \mathrm{~s}^{-1}$ if the speed is predicted from Eq. 11 and $k=7.2 \times 10^{4} 5^{-1}$ if an observed swimming speed, $20 \mu \mathrm{m} \mathrm{s}^{-1}$ (Bauerfeind et al. 1986), is used. The larger value of $k$ removes 0.963 of the original virus in $1 \mathrm{~h}$. The difference between model and observation is remarkably small and supports the notion of efficient adsorption on algal as well as bacterial hosts.

This calculation of viral contact rate assumes that a cell adsorbs any virus reaching its surface. Viruses do adsorb strongly to specific locations on the cell membrane known as receptor sites. Berg \& Purcell (1977) showed that the net diffusive flux to a cell with a small number of receptors could be nearly as large as for a perfectly adsorbing cell. Cells grown in special media to reduce the number of receptors still have relatively high adsorption rates, although lower than those of cells with normal numbers of receptors (Schwartz 1976) (Table 4). However, adsorption rate can also be affected by changes in $\mathrm{Mg}^{2+}$ concentration. This sensitivity to ionic concentration suggests that surface charge effects were important in these experiments. Electrostatic repulsion is typically less important at the ionic strength of seawater (e.g. Stumm \& Morgan 1981). As a result, it is not clear what the implications are for viruses in seawater.

\section{Enteric virus adsorption in the environment}

The sanitary engineering literature distinguishes between 2 types of interactions with particulate material: removal and inactivation (e.g. Sobsey \& Cooper 1973). Suspended solids associated with wastewater treatment systems can adsorb viruses in a reversible fashion. In Sobsey \& Cooper's (1973) system, about $1 / 3$ of the viruses attached to suspended solids present at $1 \mathrm{~g} \mathrm{l}^{-1}$ in times on the order of minutes. In addition, bacteria and algae associated with treatment systems can permanently inactivate enteric viruses. For mixed populations with bacterial concentrations of about $2 \times 10^{7} \mathrm{~cm}^{-3}$ and algal concentrations of about $1 \times 10^{6}$, $k_{\mathrm{d}}=2.8 \times 10^{-5} \mathrm{~s}^{-1}$. This is equivalent to $c_{\mathrm{d}}=1.4 \times$ $10^{-12} \mathrm{~cm}^{3} \mathrm{~s}^{-1}$ if bacteria are the dominant particles. This value of $c_{d}$ is about a factor of 10 less than the rate expected if such inactivation is limited by transport to free-living bacteria. However, the rate would be slower if dissolved virus concentrations decrease because of reversible adsorption to the suspended solids and if bacteria are attached to larger particles rather than freely living.

The destruction of human enteric viruses in seawater, where they have no hosts, provides a method for estimating viral removal rate from contact with non-host particles. Autoclaving (Carlucci \& Pramer 1960, Toranzo et al. 1982) and/or filtration of seawater (Fujioka et al. 1980) reduce bacterial concentrations and remove most of its enteric viricidal activity. Enrichment of seawater with peptone increases, and with 
penicillin decreases, enteric viral mortality (Fujioka et al. 1980). The surviving fraction of enteric viruses from both Fujioka et al. (1980) and Toranzo et al. (1982) is only $10^{-2}$ to $10^{-4}$ after 4 to $6 \mathrm{~d}\left(k_{\mathrm{d}}=1.33 \times 10^{-5}, 1.8 \times\right.$ $\left.10^{-5} \mathrm{~s}^{-1}\right)$ for an untreated sample and 0.5 to $0.25\left(k_{\mathrm{d}}=\right.$ $2.0 \times 10^{-6}, 2.7 \times 10^{-6} \mathrm{~s}^{-1}$ ) over the same period for autoclaved or filtered samples. Carlucci \& Pramer (1960) found 0.98 disappearance in seawater after $10 \mathrm{~d}$ for native marine bacteriophages $\left(k_{d}=4.5 \times 10^{-6} \mathrm{~s}^{-1}\right)$, but less than 0.5 mortality after $30 \mathrm{~d}$ in autoclaved seawater $\left(k_{d}=2.7 \times 10^{-7} \mathrm{~s}^{-1}\right)$.

Toranzo et al. (1982) observed poliovirus disappearance in samples for a range of conditions for samples taken from temperate estuaries. Their values of $c_{d}$ are fairly high, particularly those for Chesapeake Bay, USA (Table 5), but they measured bacterial concentrations using an agar culture method known to underestimate bacterial concentrations. Values of $k_{\mathrm{d}}$ for their results obtained after $30 \mathrm{~d}$ incubations (their Fig. 2) are about $6.7 \times 10^{-6} \mathrm{~s}^{-1}$ for natural seawater, $2.3 \times 10^{-6} \mathrm{~s}^{-1}$ for natural seawater with $0.2 \mathrm{~g} \mathrm{~cm}^{-3}$ of added sediment, $1.3 \times 10^{-6} \mathrm{~s}^{-1}$ for autoclaved seawater with the same amount of added sediment, and $6.97 \times 10^{-7} \mathrm{~s}^{-1}$ for autoclaved seawater. If the sediment was composed of particles with densities of $6 \mathrm{~g} \mathrm{~cm}^{-3}$ and diameter $0.2 \mathrm{~mm}$, then their expected contribution to $k$ was $4.7 \times 10^{-5} \mathrm{~s}^{-1}$; if $d$ was $2 \mathrm{~mm}$, then $k=4.7 \times 10^{-7} \mathrm{~s}^{-1}$.

The value of $c_{d}$ cannot be calculated from experimental results without an estimate of $P$. The value of $P$ expected for a given $C$ can be estimated using Eq. 13 . This has been done for coastal temperate /Carlucci \&
Pramer 1960), Hawaiian (USA) (Fujioka et al. 1980) and temperate estuarine (Zachary 1976) waters (Table 6). Estimated populations of large and small bacteria are, for all these conditions, within the rather narrow range of $2 \times 10^{4}$ to $2 \times 10^{6} \mathrm{~cm}^{-3}$. Such populations are reasonable for the marine environment (Austin 1988). A caveat is that different viral species under the same conditions can have different inactivation rates which are not simply explainable using transport rates (Metcalfe et al. 1974).

\section{Native viruses in the environment}

Heldal \& Bratbak (1991) measured viral disappearance rates of natural viruses in Norwegian coastal waters. Their decay rates are high (Table 5), indicating a high efficiency of inactivation. Specific decay rates for the observed bacteria are ca 20 to $120 \mu^{3} \mathrm{~s}^{-1}$, but calculated perfect specific decay rates are 18 to $35 \mu \mathrm{m}^{3} \mathrm{~s}^{-1}$. Decay appears to be up to 6 times faster than perfect adsorption would support. Bratbak et al. (1992) have shown that bacterial production rates are inconsistant with viral production rates. As a result this set of numbers is flawed.

The similar rates for the disappearance of both native and exotic viruses may suggest that mass transport to all particles controls viral populations in natural waters but, as with any general rule applied to a natural system, there are exceptions. The presence of the bacterium Bacillus megaterium had little effect

Table 5. Comparison of removal rates of viruses by ideal bacteria with rates observed at various locations. Specific removal of viruses by bacteria is calculated from decay rates and bacterial population observations. Model calculations of viral removal rate are shown for hypothetical standard large and small bacteria (see Table 3 )

\begin{tabular}{|c|c|c|c|c|c|c|}
\hline Location & Virus & $\begin{array}{c}t \\
\text { (d) }\end{array}$ & $\left(10^{k_{i}} \mathrm{~s}^{-1}\right)$ & $\begin{array}{c}B \\
\left(10^{6} \mathrm{~cm}^{-3}\right)\end{array}$ & $\left(\mu \mathrm{m}^{3} \mathrm{~s}^{-1}\right)$ & Source \\
\hline Pontevedra, Spain & Poliovirus & 6.5 & 8.2 & 0.1 & 82 & Toranzo et al. (1989) \\
\hline Pontevedra, Spain & Poliovirus & 16.5 & 4.9 & 0.1 & 49 & Toranzo et al. (1989) \\
\hline Chesapeake Bay, USA & Poliovirus & 6.5 & 8.2 & 0.032 & 250 & Toranzo et al. (1989) \\
\hline Chesapeake Bay, USA & Poliovirus & 9.5 & 8.4 & 0.032 & 260 & Toranzo et al. (1989) \\
\hline Large bacteria & Poliovirus & - & - & - & 100 & This study (Table 3 ) \\
\hline Small bacteria & Poliovirus & - & - & - & 45 & This study (Table 3 ) \\
\hline MBD harbor, Norway ${ }^{d}$ & Native & 0.042 & 83 & 4.4 & 19 & Heldal \& Bratbak (1991) \\
\hline Bergen harbor, Norway & Native & 0.042 & 310 & 2.9 & 110 & Heldal \& Bratbak (1991) \\
\hline Raunefjorden, Norway & Native & 0.042 & 140 & 1.4 & 97 & Heldal \& Bratbak (1991) \\
\hline Raunefjorden, Norway & Native & 0.042 & 150 & 1.5 & 100 & Heldal \& Bratbak (1991) \\
\hline Raunefjorden, Norway & Native & 0.042 & 72 & 0.7 & 100 & Heldal \& Bratbak (1991) \\
\hline Lake Kalandsvannet, Norway & Native & 0.042 & 97 & 3. & 32 & Heldal \& Bratbak (1991) \\
\hline Lake Kalandsvannet, Norway & Native & 0.042 & 180 & 4.1 & 43 & Heldal \& Bratbak (1991) \\
\hline Lake Kalandsvannet, Norway & Native & 0.042 & 92 & 8 & 1.20 & Heldal \& Bratbak (1991) \\
\hline Large bacteria & Native & - & - & - & 35 & This study (Table 3) \\
\hline Small bacteria & Native & - & - & - & 18 & This study (Table 3 ) \\
\hline
\end{tabular}


Table 6. Estimated bacterial populations obtained from observed viral decay rates and calculated viral clearance rate (c) for hypothetical standard large bacteria (see Table 4). Values of $c$ are about half and values of B are about twice these for small bacteria

\begin{tabular}{|c|c|c|c|c|c|c|}
\hline Location & Virus & $\begin{array}{c}t \\
\text { (d) }\end{array}$ & $\begin{array}{c}k_{\mathrm{tl}} \\
\left(10^{-b} \mathrm{~s}^{-1}\right)\end{array}$ & $\frac{c_{d}}{\left(\mu m^{3} s^{-1}\right)}$ & $\begin{array}{c}B \\
\left(10^{6} \mathrm{~cm}^{-3}\right)\end{array}$ & Source \\
\hline Long Branch, New Jersey, USA & Standard & 10 & 4.5 & 35.2 & 0.18 & Carlucci \& Pramer (1960) \\
\hline Waianae Coast, Hawail, USA & Poliovirus & 4 & 10 & 104 & 0.2 & Fujioka et al. (1980) \\
\hline Mokapu Point, Hawaii, USA & Poliovirus & 4 & 18 & 104 & 0.36 & Fujioka et al. (1980) \\
\hline Open Ocean, Hawaii, USA & Poliovirus & 4 & 18 & 104 & 0.36 & Fujioka et al. (1980) \\
\hline Nuuanu Stream, Hawaii, USA & Poliovirus & 4 & 4.7 & 104 & 0.093 & Fujioka et al. (1980) \\
\hline Nuuanu Mouth, Hawaii, USA & Poliovirus & 4 & 15 & 104 & 0.29 & Fujioka et al. (1980) \\
\hline Control (artificial seawater) & Poliovirus & 4 & 3.3 & 104 & 0.067 & Fujioka et al. (1980) \\
\hline Estuary, York River, Virginia, USA & $\mathrm{nt}-1$ & 10 & 2.3 & 33 & 0.068 & Zachary (1976) \\
\hline Estuary, York River, Virginia, USA & $\mathrm{nt}-1$ & 30 & 0.82 & 33 & 0.011 & Zachary (1976) \\
\hline Estuary, York River, Virginia, USA & nt-6 & 10 & 1.1 & 45 & 0.024 & Zachary (1976) \\
\hline Estuary, York River, Virginia, USA & nt -6 & 30 & 1.8 & 45 & 0.039 & Zachary (1976) \\
\hline Houston Ship Channel, Texas, USA & Poliovirus & 7 & 5.8 & 104 & 0.056 & Metcalfe et al. (1974) \\
\hline Houston Ship Channel, Texas, USA & Coxsachievirus & 7 & 0.31 & 104 & 0.003 & Metcalfe et al. (1974) \\
\hline Houston Ship Channel, Texas, USA & Echovirus & 7 & 0.62 & 104 & 0.066 & Metcalfe et al. (1974) \\
\hline
\end{tabular}

on the viral removal rate in sewage effluent (Sobsey \& Cooper 1973). There may be marine organisms which do not adsorb all viruses. However, the interesting observations remain that viral disappearance rates do seem to be related to particle concentrations and mass transport rates.

\section{Calculated host:virus contact rates for particle distributions}

The value of $k$ depends on target particle numbers as well as on their sizes. Particles in the environment occur over a range of sizes that are described by particle size distributions. Sheldon et al. (1972) described an average particle size distribution in which there are equal particle volumes in equal logarithmic size ranges. For such a size distribution, there are far fewer numbers of particles in the larger size ranges. As a result, the largest fraction of viruses would be transported to the smaller particles (Table 2). The relative transport depends also on the behaviour of the host particles. Total viral transport to bacteria is 16700 times faster than that to large dinoflagellates, if diffusion alone cause viral transport, but only 1500 times faster if both organisms are motile.

The viral contact rate is not so neatly distributed for the skewed particle distributions that are more typical of real situations (e.g. Holligan et al. 1984). Observed biomass levels for organisms between 2 and $90 \mu \mathrm{m}$ diameter in surface waters of the English Channel vary with hydrographic conditions (Fig. $4 \mathrm{~b}$ to d). The distri- bution of $k$ as a function of particle size is slightly skewed to larger particles for the case of the stratified water column because of a small peak of 3 to $4 \mu \mathrm{m}$ organisms (Fig. 4b). In the case of mixed water, where smaller plankton accounted for only a very small proportion of biomass, small organisms still have the higher contact rates (Fig. $4 \mathrm{~d}$ ). In all cases phytoplankton with diameters ranging from 10 to $50 \mu \mathrm{m}$ dominated the biomass distribution but did not appreciably affect the contact rate distribution. Again, the small plankton dominated viral mass transport to particles.

The proportion of biomass contributed by bacteria can be very small. For example diatoms can be present at densities of $10^{4}$ cells $\mathrm{cm}^{-3}$ in Norwegian coastal waters, and the dominant species is Skeletonema costatum (Bratbak et al. 1990). The volume of this phytoplankter is 0.4 to $1 \times 10^{3} \mu^{3}$ (Raymont 1980). Biovolumes of up to $10^{7} \mu^{3} \mathrm{~cm}^{-3}$ may be present. even though bacteria do not exceed $4 \times 10^{4} \mu \mathrm{m}^{3} \mathrm{~cm}^{-3}$ in biovolume. Therefore if viral mortality were simply proportional to organism biomass, as it might be if free exudates were responsible, bacteria would be unlikely to play a significant role.

\section{DISCUSSION}

Diffusive processes place an upper bound on the rate at which viruses can interact with particles, including organisms. If the particle happens to be a host cell, the virus can infect it. More interesting than such infections are the interactions which remove viruses from 

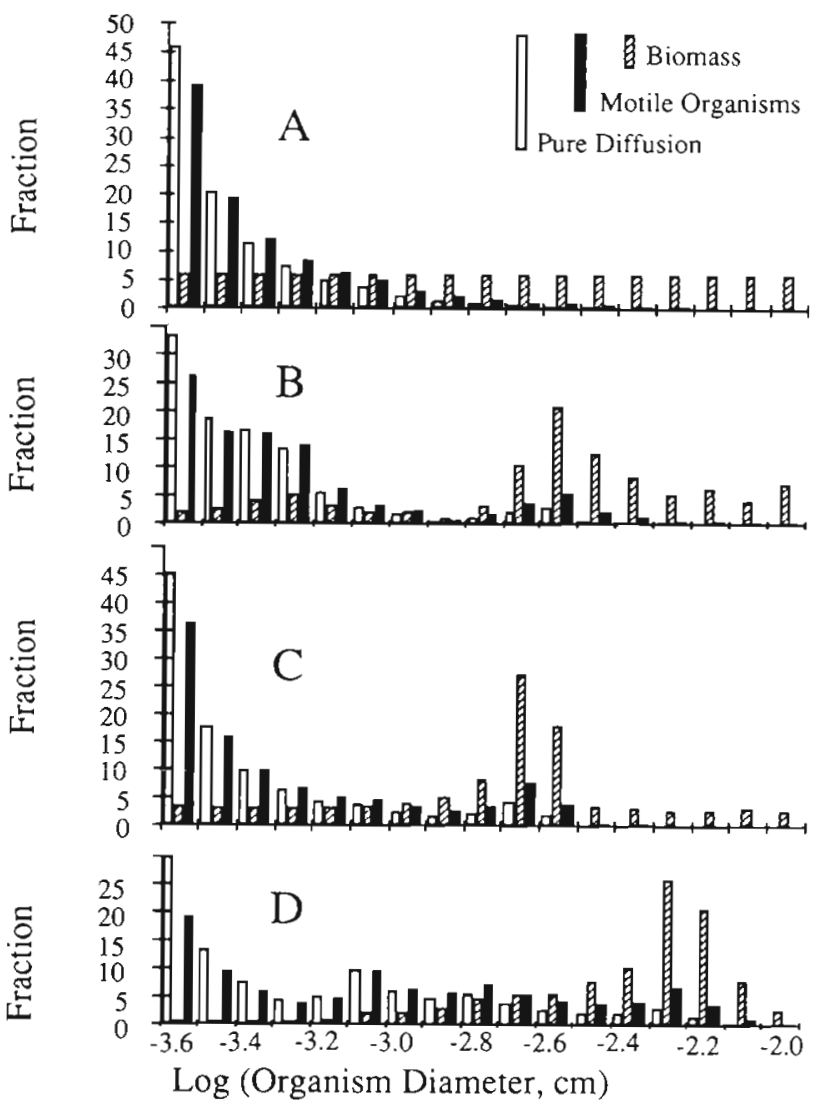

Fig. 4. Distribution by size fraction (expressed as a percentage) of cell:virus contacts and cell volume for idealized particle spectrum and particle spectra observed in the English Channel by Holligan et al. (1984). Size range is 2 to $90 \mu \mathrm{m}$. Shown are the expected contact rates if the particles are not motile, with pure diffusion determining particle transport, and if they are motile, with a size-swimming velocity relationship given in Eq. 11 (A) Idealized distribution with equal particle volume in equal logarithmic diameter intervals; (B) stratified waters; (C) frontal waters; (D) mixed waters. Biomass for (B) to (D) from Holligan et al. (1984)

solution, either temporarily or permanently. The surprising thing about the comparisons made above between calculated and observed rates of viral disappearance is how well. the mass transport estimates agree with the measurements, suggesting that transport to particle surfaces is a fundamental part of viral inactivation. There has been extensive exploration of viral removal by particles, particularly in the sanitary engineering literature. The results, partially reviewed by Gerba (1984), are ambiguous

Valentine \& Allison (1959) compared the rates at which viruses appeared on non-biological surfaces with the rates predicted from diffusion theory. They observed that prediction from diffusion theory fit the rates of viral attachment to inorganic surfaces for sufficiently high ionic strengths. However, the presence of soluble protein slowed the adsorption rate, presumably by altering surface properties. When they extended the comparison to viral transfer onto suspended animal cells, they found that the maximum adsorption rate was a third the predicted diffusive transport rate or less (Allison \& Valentine 1960a). The adsorption rate was sensitive to the ionic composition of the medium (Allison \& Valentine 1960b). Their highest adsorption rates for cell monolayers were half the predicted values and were at cation concentrations similar to those of seawater. The reversibility of the adsorption process varied with the cell culture, with some showing almost no elution of adsorbed viruses when placed in fresh, virus-free media.

Reversible adsorption has been found in sewage systems, where the suspended solids concentrations are 3 orders of magnitude larger than those in the ocean (e.g. Sobsey \& Cooper 1973). It has also been observed in sediment suspensions in experiments in which the sediment concentrations were very high, about 0.2 of the sample volume (e.g Smith et al. 1978, LaBelle \& Gerba 1980). This adsorption to inorganic sediments has been invoked to explain high concentrations of viruses in benthic sediments (e.g. Metcalfe et al. 1974). While temporary adsorption does not constitute a fate, it does affect the viral fate by decreasing the rate at which viruses diffuse to other particles. In this sense, it acts as a chelator does to lower the activity of metal ion activity in solution (e.g. Stumm \& Morgan 1981). Surface adsorption both lowers the rate at which viruses diffuse to their hosts because the dissolved concentration is lower and increases the amount of time that viruses are vulnerable to other mortality mechanisms. If reversible adsorption in the sea is proportional to the lower particulate concentration there, reversible adsorption should be negligible in the ocean.

Preston \& Farrah (1988) argued that the thermodynamics of virus adsorption indicated that it was controlled by electrostatic and hydrophobic interactions rather than by chemical processes. For this reason, the kinetics of adsorption should be different in the high ionic strength medium of seawater than in the relatively fresh water medium of sewage effluent (e.g. Stumm \& Morgan 1981).

The virus that reaches a particle may be permanently bound to the surface or it may be destroyed by extracellular enzymes. Cliver \& Herrmann (1972) found that some bacterial species were able to inactivate strains of poliovirus and coxsackievirus more rapidly than others. They observed virus survival equivalent to $k_{d}=8.6 \times 10^{-6} \mathrm{~s}^{-1}$ and $c_{d}=0.06$ and $0.4 \mu^{3} \mathrm{~s}^{-1}$ viruses incubated with Pseudomonas aeruginosa in filtered lake water. They concluded that inactivation resulted from the presence of proteolytic 
enzymes on active bacteria. These values of $c_{d}$ are significantly smaller than the inactivation rates expected for transport limited inactivation and slower than other observed inactivation rates (Table $4 \& 5$ ). Because the large concentrations of non-native bacteria inoculated into the filtered lakewater could have had trouble surviving for the 4 and $14 \mathrm{~d}$ lengths of the incubations, these rates probably represent only a minimum value.

Toranzo et al. (1982) argued that cell-free exudates inflicted high viral mortality. This result is in contradiction to the observations of Fujioka et al. (1980) who argued that fine filters $(0.2 \mu \mathrm{m})$ removed all viricidal activity. It is possible that filtration could release chemicals normally bound to or associated with the cell and normally requiring contact to be effective in deactivating viruses. Karner \& Herndl (1992) found that particle-bound extracellular enzymatic activity was much greater than that for dissolved activity in marine snow but was similar in size for free-living bacteria. If a cell produces free dissolved antiviral agents then diffusion theory predicts that this concentration will vary inversely with distance from the cell. Even if free exudates are responsible for viral deactivation their activities should be highest in the region near the excreting cell.

The continuing decrease of viral numbers at fairly constant rates that have been observed in seawater incubations as long as 1 mo suggest that dissolved viruses do not equilibrate with those adsorbed to particles. If adsorption on the outside of cells is the primary process for viral inactivation, it is effectively permanent, Viral inactivation could be caused by extracellular enzymes on bacterial particles that are more efficient than those measured by Cliver \& Herrmann (1972). Such greater efficiencies could be possible in bacteria which have evolved in the dilute oceanic medium. Exoenzymes are not confined to the bacteria but have been reported for other taxa (Chróst 1990). If this were the dominant mechanism for viral inactivation, then larger algal species could have a smaller role in viral inactivation than we have calculated.

The results presented here show that, for any given viral concentration, a large particle is more likely to have a virus reach its surface. This probability is enhanced by particle motions. Any given virus, however, is far more likely to reach a small, presumably bacterial, particle than a larger one in the ocean because of the greater abundance of small particles for normal particle size distributions. This is in spite of the enhanced transport to larger moving organisms.

To maintain its population, a virus must, on average, have at least one of its progeny successfully infecting a member of its host species. If too many adsorb on to the wrong particles, then the infection is not viable. To the extent that a species is equivalent to a size class, the high movement to the small particles make it more difficult for a virus to maintain an infection of a larger species, like a dinoflagellate, than to a small one, like a bacterium. Exceptions to this might be bloom conditions. If there are more species present in the small size categories than in the large, this need not be the case Viral infections could preferentially encourage speciation in the small size classes over the large.

A virus could increase its targeting of large particles by increasing its diffusivity. The transport rate for a small particle having a small $P e$ is proportional to $D_{v}$. For a larger swimming particle with sufficiently large $\mathrm{Pe}$, the $\mathrm{Sh}$ enhancement is proportional to $\mathrm{Pe}^{-3}$ and. hence, to $D_{v}{ }^{-1 / 3}$. Total transport for the large particle is proportional to $D_{v}{ }^{2 / 3}$. A decrease in $D_{v}$ by a factor of 10 would decrease the viral transport to the small particle by 10 but the large particle by only 4.6. As a result the relative transport is larger by more than 2 . A virus could decrease $D_{\mathrm{y}}$ by increasing its size. Viral diffusion coefficients calculated from virus radii do show a tendency to decrease for larger hosts (Fig. 4). This is suggestive but not definitive evidence that mass transport is important in determining viral success in reaching a host.

Viruses could affect larger hosts by producing more offspring. There appears to be little evidence of as a strong increase in burst sizes as required by previous calculations. For example the alga Micromonas pusilla has a burst size of 72 (Waters \& Chan 1982), similar to the average burst size of bacteria, which ranges from 50 to 100 (Heldal \& Bratbak 1991), despite the former's far larger cell volume. This implies that viral infection is, in fact, a less important cause of mortality for larger organisms than it is for bacteria. However more data is needed in order to draw firm conclusions. Burst size is highly variable, even for a single species of bacteria (Delbruck 1945) and varies with environmental factors such as salinity and temperature (Zachary 1976, 1978).

If viruses can target larger hosts by decreasing their diffusivity, hosts can decrease exposure by decreasing motility. This will both increase the time that viruses are exposed to environmental degradation and increase their relative contact with bacteria. However small movements generate relatively large $S h$ values for large organisms and as speed increases, increase in Sh decreases (Fig. 5). Therefore marginal decrease in swimming speed will bring little benefit to an organism exposed to viruses but complete immobility greatly reduces its vulnerability.

Wolkin \& Pate (1986) found a mutant of the gliding bacterium Cytophaga johnsonae which was incapable of movement. Associated with this characteristic was a weakened ability to attach to surfaces and decreased 


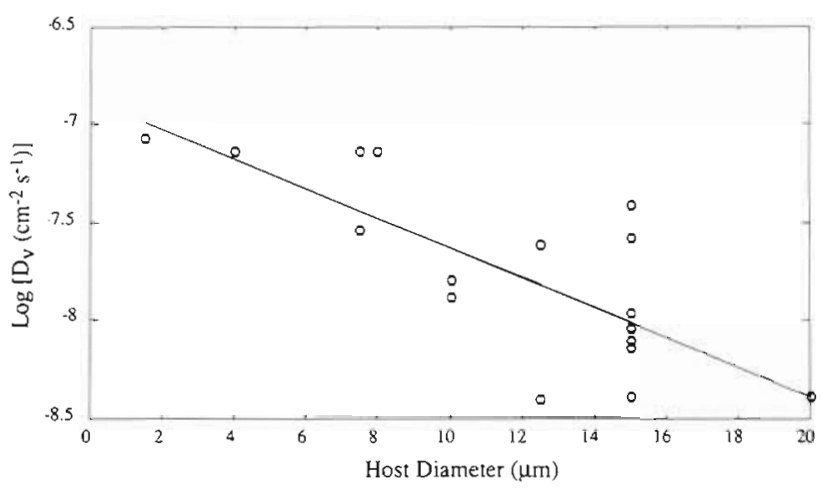

Fig. 5. Relationship between calculated viral diffusion coefficient and host diameter for viruses of aquatic unicellular eukaryotic algae. Viral diffusivity calculated using Eq. 9. A linear regression analysis yielded: $\log D_{v}\left(\mathrm{~cm}^{2} \mathrm{~s}^{-1}\right)=$ $-6.87-758 d(\mathrm{~cm})\left(\mathrm{r}^{2}=0.6\right)$. Viral diameters from Van Etten et al. (1991), algal diameters from Raymont (1980), Smith (1955) and Sieburth (1980)

adsorption of viruses. It is interesting to speculate that the ability to adhere to particles is associated with an increased susceptibility to viral adsorption and that this may be the reason for the widely quoted tendency of bacteria in seawater to be free-living (e.g. Azam \& Hodson 1977).

Uitraviolet radiation is known to inactivate viruses. Harm (1980) observed the disappearance of the bacteriophage T4 in surface sunlight. The surviving popuJation can be described by a value of $k_{d}=3 \times 10^{-4} \mathrm{~s}^{-1}$, larger than most of the values of $k$ and $k_{\mathrm{d}}$ noted in this article for mass transport. This rate should decrease rapidly with depth in the water column because of the rapid UV attenuation in seawater (e.g. Smith \& Baker 1979). Other forms of mortality may be due to dissolved biologically produced viricides active at a distance from cells (Toranzo et al. 1982) or heavy metals (Bitton 1980). The importance of both these forms of mortality is uncertain.

Johnson \& Kepkay (1992) have recently analyzed the potential rates of bacterial feeding on colloids by using a particle-particle interaction approach. They divide collisions between particles into the mechanisms known to bring particles together, Brownian motion, bacterial swimming, and turbulent shear They found that Brownian motion was the important process for bacteria feeding on small colloids. Viruses are colloidal particles. As a result, Johnson \& Kepkay provided an alternative approach that is very similar to that developed here. The collision rate for Brownian motion used in the particle-particle approach reduces to Eq. 1 when one particle is much larger than the other, a condition fulfilled by viruses diffusing to bacteria. An advantage of our approach is that it allows for the interaction of bacterial swimming and viral diffusion. The particle- particle approach assumes that the processes do not interact. As a result, the approach of Johnson \& Kepkay (1992) does not include the transport enhancement incorporated in Sh. While not very large for bacteria, it is important for larger organisms.

Colloidal particles, which have been observed in seawater (e.g. Wells \& Goldman 1991), could also adsorb viral particles. The low adsorption by the heterogeneous sewage sludge would suggest that such amorphous organic matter may not adsorb viruses very readily.

Transport in the environment will be affected by a range of factors which have been neglected here. Molecular viscosity can vary by a factor of 2 because of temperature changes (e.g. Neumann \& Pierson 1966). This affects the value of $D_{v}$. Additionally, even bacteria in monocultures have a range of sizes and swimming speeds (e.g. Koppes et al. 1978), not a single set of values. Their sizes vary with physiological conditions induced by environmental changes. There will always be a certain imprecision in the estimates of mass transport.

The potential importance of viral adsorption rates in the presence of particles, target and non-target, suggests that the determination of particle numbers and sizes should be an important part of experiments to measure viral disappearance rates. Results from such experiments are better presented as rates rather than as fraction remaining after a period of time because very similar rates can be made to appear very different when comparing survivorship after suitably long periods of time.

The frequent observations that non-host bacteria and algae reduce viral concentrations suggest that transport to cell surfaces and subsequent inactivation may be a very important fate for viruses. The fact that these inactivation rates are of the same order as the rates we have calculated for viral transport suggests that transport is an important part of the viral inactivation process.

The data presented suggest that biological activity plays a very significant role in viral mortality. The model suggests, and calculations using observations support, the notion that bacterial biomass is a critical parameter in evaluation of viral mortality. Further information is required on the proportion of viruses that are adsorbed by non-host organisms, but the particle contact model provides the maximum limit. This maximum rate appears appropriate for calculating the removal of enteric viruses from seawater by particulate processes. A complete description of viral removal in the environment would require the incorporation of such other mechanisms as UV light inactivation of viruses.

Acknowledgements. This work was supported by Office of Naval Research Contract N00014 87-K0005 and U.S. Department of Energy grant DE-FG05-85-ER60341 


\section{LITERATURE CITED}

Acrivos, A. (1971). Heat transfer at high Peclet number from a small sphere freely rotating in a simple shear field. J. Fluid Mech. 46: 233-240

Allison, A. C.., Valentine, R. C. (1960a) Virus particle adsorption. II. Adsorption of vaccinia and fowl plague viruses to cells in suspension. Biochim. Biophys. Acta 40: 393-399

Allison, A. C., Valentine, R. C. (1960b) Virus particle adsorption. III. Adsorption of viruses by cell monolayers and effects of some variables on adsorption. Biochim. Biophys. Acta 40:400-410

Anderson, T. F. (1949). The reactions of bacterial viruses with their host cells. Bot. Rev. 15: 464-505

Austin, B. (1988). Marine microbiology. Cambridge University Press

Azam, F. Hodson, R. E. (1977). Size distribution and activity of marine microheterotrophs. Limnol. Oceanogr. 22: 492-501

Batchelor, G. K. (1979). Mass transfer from a particle suspended in fluid with a steady linear ambient velocity distribution. J. Fluid Mech. 95: 369-400

Bauerfeind, E., Elbrachter, M., Steiner, R., Throndsen, J (1986). Application of laser doppler spectroscopy (LDS) in determining swimming velocities of motile phytoplankton Mar. Biol. 93: 323-327

Berg, H. C. (1983). Random walks in biology. Princeton University Press, Princeton

Berg, H. C., Purcell, E. M. (1977). Physics of chemoreception. Biophys. J. 20: 193-219

Berg, O., Borsheim, K. Y., Bratbak, G., Heldal, M. (1989). High abundance of viruses found in aquatic environments Nature 340: 467-468

Bitton, G. (1980). Introduction to environmental virology Wiley-Interscience, New York

Bratbak, G., Heldal, M., Norland, S., Thingstad, T. F. (1990) Viruses as partners in spring bloom microbial trophodynamics. Appl. environ. Microbiol. 56: 1400-1405

Bratbak, G., Heldal, M., Thingstad, T F, Riemann, B., Haslund, O. H. (1992). Incorporation of viruses into the budget of microbial C-transfer. A first approach. Mar. Ecol. Prog. Ser. 83: 273-280

Carlucci, A. F., Pramer, D. (1960). An evaluation of factors affecting the survival of Escherichia coli in sea water. IV. Bacteriophages. Appl. Microbiol 8: 254-256

Chróst, R. J. (1990). Microbial ectoenzymes in aquatic environments. In: Overbeck J., Chróst, R. J. (eds.) Microbial ecology. Springer-Verlag, New York, p. 47-78

Clift, R., Grace, J. R., Weber, M. E. (1978). Bubbles, drops, and particles. Academic Press, New York

Cliver, D. O., Hermann, J. E. (1972). Proteolytic and microbial inactivation of enteroviruses. Water Res. 6: 797-805

Delbruck, M. (1945). The burst size distribution in the growth of bacterial viruses (Bacteriophages). J. Bacteriol. 50: $131-135$

Dubin, S. B., Benedek, G. B., Bancroft, F. C., Freifelder, D (1970). Molecular weights of coliphages and coliphage DNA II. Measurement of diffusion coefficients using optical mixing spectroscopy, and measurement of sedimentation coefficients. J. molec. Biol. 54: 547-556

Fenchel, T. (1987). Ecology of Protozoa. Springer-Verlag, Berlin

Frankel, N. A., Acrivos, A. (1968). Heat and mass transfer from small spheres and cylinders freely suspended in shear flow. Phys. Fluids 11: 1913-1918

Fujioka, R. S., Loh, P. C., Lau, S. L. (1980). Survival of human enteroviruses in the Hawaiian ocean environment: evi- dence for virus inactivating microorganisms. Appl. environ. Microbiol. 39: 1105-1110

Gerba, C. P. (1984). Applied and theoretical aspects of virus adsorption to surfaces. Adv. appl. Microbiol. 30: 133-168

Gregg, M. C., Peters, H., Wesson, J. C., Oakey, N. S., Shay, $T$ J. (1985). Intensive measurements of turbulence and shear in the equatorial undercurrent. Nature 318: 140-144

Harm, W. (1980). Biological effects of ultraviolet radiation. Cambridge University Press, Cambridge

Heldal, M., Bratbak, G. (1991). Production and decay of viruses in aquatic environments. Mar Ecol. Prog. Ser 72 $205-212$

Holligan, P. M. Harris, R. P., Newell, R. C., Harbour, D. S., Head, R. N., Linley, E. A. S., Lucas, M. I., Tranter, P. R. G, Weekley, C. M. (1984). Vertical distribution and partitioning of organic carbon in mixed, frontal and stratified waters of the English Channel. Mar. Ecol. Prog. Ser. 14: 111-127

Hughs, W. F., Brighton, J A. (1991). Fluid dynamics. McGraw-Hill, New York

Jackson, G. A. (1990). A model of the formation of marine algal flocs by physical coagulation processes. Deep Sea Res. 37: 1197-1211

Johnson, B. D., Kepkay, P. E. (1992). Colloid transport and bacterial utilization of DOC. Deep Sea Res. 39: 855-869

Karner, M., Herndl, G. J. (1992) Extracellular enzymatic activity and secondary production in free-living and marine-snow-associated bacteria. Mar. Biol. 113: 341-347

Koppes, L. J. H., Woldringh, C. L., Nanninga, N. (1978). Size variations and correlation of different cell cycle events in slow-growing Escherichia coli. J. Bacteriol. 134: 423-433

LaBelle, R. L., Gerba, C. P. (1980). Influence of estuarine sediment on virus survival under field conditions. Appl. environ. Microbiol. 39: 749-755

Logan, B. E., Dettmer, J W. (1990). Increased mass transfer to microorganisms with fluid motion. Biotechnol. Bioengng. Symp. 35: 1135-1144

Maeda, M., Taga, N. (1983). Comparison of cell size of bacteria from four marine locations. La Mer 21. 207-210

Metcalfe, $\Upsilon$ G., Wallis, C., Melnick, J. L. (1974). Virus enumeration and public health assessments in polluted surface water contributions to transmission of virus in nature. In: Malina, J. F. Jr, Sagik, B. P. (eds.) Virus survival in water and wastewater systems. University of Texas Press, Austin, p. 57-79

Munk, W. H., Riley, G. A. (1952). Absorption of nutrients by aquatic plants. J. mar. Res. 11: 215-240

Neumann, G., Pierson, W. J. Jr (1966). Principles of physical oceanography. Prentice-Hall, Englewood Cliffs

Pienaar, R. N. (1976). Virus-like particles in three species of phytoplankton from the San Juan Islands. Phycologia 15: $185-190$

Preston, D. R., Farrah, S. R. (1988). Activation thermodynamics of virus adsorption to solids. Appl. environ. Microbiol. 54: $2650-2654$

Proctor, R. M., Fuhrman, J. A. (1990). Viral mortality of marine bacteria and cyanobacteria. Nature 343: 60-62

Raymont, J. E. G. (1980). Plankton and productivity in the aceans. Vol. I, Phytoplankton, 2nd edn. Pergamon Press, Oxford

Roberts, A. M. (1981). Hydrodynamics of protozoan swimming In: Levandowski, M., Hutner, S. H. (eds.) Biochemistry and physiology of protozoa, 2nd edn. Academic Press, New York

Schlesinger, M. (1932). Absorption of bacteriophages to homologous bacteria. (Translated) in Stent, G. S. (ed.) (1960) Bacterial viruses. Little, Brown and Co., Boston, p. $26-36$ 
Schwartz, M. (1976). The adsorption of coliphage Lambda to its host: effect of variation in the surface density of receptor and in phage-receptor affinity. J. molec. Biol. 103: 521-536

Sheldon, R. W., Prakash, A., Sutcliffe, W. H. Jr (1972). The size distribution of particles in the ocean. Limnol. Oceanogr 17: $327-340$

Sieburth, J. McN. (1980). Sea microbes. Oxford University Press, New York

Smayda, T J. (1970). The suspension and sinking of phytoplankton in the sea. Oceanogr. mar. Biol. Ann. Rev, 8: 353-414

Smith, E. M., Gerba, C. P., Melnick, J. L. (1978). Role of sediment in the persistence of enteroviruses in the estuarine environment. Appl. environ. Microbiol. 35: 685-689

Smith, G. M. (1955). Cryptogamic botany. Vol. I. Algae and fungi. McGraw-Hill, New York

Smith, R. C., Baker, K. S. (1979). Penetration of UV-B and biologically effective dose-rates in natural waters. Photochem. Photobiol. 29: 311-323

Sobsey, M. D., Cooper, R. C. (1973). Enteric virus survival in algal-bacterial wastewater treatment systems - I. Laboratory studies. Water Res. 7: 669-685

Stumm, W., Morgan, J. J. (1981). Aquatic chemistry, 2nd edn Wiley-Interscience, New York

Suttle, C. A., Chan, A. M., Cottrell, M. T. (1990). Infection of phytoplankton by viruses and reduction of primary productivity. Nature 347: $467-469$

Tolmach, L. J. (1957). Attachment and penetration of cells by viruses. Adv. Virus Res. 4: 63-110

Toranzo, A. E., Baria, J L., Hetrick, F. M. (1982). Antiviral activity of antibiotic-producing marine bacteria. Can. J. Microbiol. 28: 231-238

This article was submitted to the editor
Vaituzis, Z., Doetsch, R. N. (1969). Motility tracks: technique for quantitative study of bacterial movement. Appl. Microbiol 17: $584-588$

Valentine, R. C., Allison, A. C. (1959). Virus particle adsorption. I. Theory of adsorption and experiments on the attachment of particles to non-biological surfaces. Biochim. Biophys. Acta 34: 10-23

Van Etten, J. L., Lane, L. C., Meints, R. H. (1991). Viruses and viruslike particles of eukaryotic algae. Microbiol. Rev. 55 $586-620$

Waters, R. E., Chan, A. T. (1982). Micromonas pusilla virus: the virus growth cycle and associated physiological events within the host cells; host range mutation. J. gen. Virol. 63: $199-206$

Wells, M. L., Goldman, E. D. (1991). Occurrence of small colloids in sea water. Nature 353: 342-344

Wiggins, B. A., Alexander, M. (1985). Minimum bacterial density for bacteriophage replication: implications for significance of bacteriophages in natural ecosystems. Appl environ. Microbiol. 49: 19-23

Wolkin, R. H., Pate, J. L. (1986). Phage adsorption and cell adherence are motility-dependent characteristics of the gliding bacterium Cytophaga johnsonae. J. gen. Microbiol. 132: $355-367$

Zachary, A. (1976). Physiology and ecology of bacteriophages of the marine bacterium Beneckea natrigens: salinity. Appl. environ. Microbiol. 31:415-422

Zachary, A. (1978). An ecological study of bacteriophages of Vibrio natrigens. Can. J. Microbiol. 24: 321-324

Zimmerman, R., Meyer-Reil, L. A. (1974). A new method for fluorescence staining of bacteria populations on membrane filters. Kieler Meeresforsch. 30: 24-27

Manuscript first received: August 17, 1992

Revised version accepted: October 28, 1992 